\title{
Ascertaining the Determinants of Private Investment in Ethiopia (1980-2017): Evidence from ARDL Approach
}

\author{
Kidane Alemu Ago \\ Lecturer, College of Business and Economics, Department of Economics, Dembi Dollo University, Dembi Dollo \\ Ethiopia
}

\begin{abstract}
The study aimed to ascertain the major determinants of private investment in the country over the period 19802017. The ARDL approach was adopted and it revealed that private investment, real gross domestic product, public investment, real effective exchange rate, inflation rate and credit to private sector are co-integrated.Real GDP had direct effect on private investment in the long-run and short-run; while public investment had negative impact. In the short-run, credit to private sector had positive effect on private investment. The overall implication is that real GDP and public investment are the main determinants of private investment in the country.
\end{abstract}

Keywords: ARDL, Ethiopia, Private investment

DOI: $10.7176 /$ RJFA/11-11-01

Publication date:June 30th 2020

\section{INTRODUCTION}

Investment in general and private investment in particular plays a vital role in expanding the productive capacity of the economy and promoting the long term economic growth. (Jongwanich\& Kohpaiboon: 2008) Despite the fact that less-developing countries gave attention to promote private investment through their regulatory bodies (egg. In Ethiopia, Ethiopian Investment Authority is mentioned), in the less-developed countries including Ethiopia, private businesses frequently operate in investment climates that undermine their incentive to invest and grow. For instance, the Ethiopian investors complain about poor infrastructure, particularly power shortages; poor transport; poor telecom connectivity of business locations and lack of efficient tax administration. (Mima \& David: 2012)Consequently, the growth rate of investment is much lower in developing countries than in developed countries (Khan et al :1996) Although Ethiopia has been registering a remarkable economic growth over the past twelve years since 2004, the annual per capital income of the country and contribution of private investment to it remain very low. (World Bank: 2013)

In spite of various macro-economic and political reforms and ranges of investment incentives given, private investors have remained very shy to make significant strides in Ethiopia. Hence, the private investment development potential is far under fetched. This suggests that, in the face of present-day international competitions, promoting private investment should be approached with locally fit and globally responsive investment policies and strategies based on contemporary and contextualized empirical researches .(Deneke:2001)

Few and scant studies on the topic in Ethiopia find out that real gross domestic product, real exchange rate, public investment, consumer price index, budget deficit, credit availability to the private sector and interest rate explained the performance private investment. However, the effect of such factor varies depending on the time period covered and methodology followed. (Abdishu: 2000; Hailu \& Debele: 2015)Most of the contemporary studies done in the country used traditional econometric analysis techniques such as OLS and ECM. Some of them are even based on cross-country experiences which neglects heterogeneity in structure across the economies. Therefore, this study was an attempt to ascertain the major determinants of private investment in Ethiopia using the most resent time series data over the period 1980-2017 fit ARDL Model, which is the most popular contemporary approach in economic literature. Specifically, the study was initiated to address the following research questions:

- What is the impact of credit to private sector on private investment?

- What is the impact of real effective exchange rate on private investment?

- What is the effect of inflation rate on private investment?

- What is the effect of economic growth (growth in real GDP) on private investment?

- Does public investment crowd-out private investment?

\section{DATA AND METHODOLOGY}

The study relied on secondary data. Observations on the selected major determinants of private investment over 38 years (that is, over the period 1980-2017) were obtained from different institutions in Ethiopia. Specifically, data on real effective exchange rate, inflation rate and real Gross Domestic Product were obtained from National Bank of Ethiopia (NBE) whereas data on private investment, public investment, credit to private sector were obtained from Ministry of Finance and Economic Development(MoFED).In attempt to determine the short run 
and long run effects of the considered variables on private investment, the study adopted Auto Regressive Distributed Lag model(ARDL) and Error Correction model(ECM) along with contemporary unit root and diagnostic testing procedures for time series data. Empirical model estimations and data analysis have been facilitated using Eviews10 software package.

\subsection{Model Speciation}

Following the formal frame work of studying private investment in developing countries developed by Blejer \& Khan(1984);Wai \& Young as cited in Francis et al (2012) and the empirical model by Marbuah and Frimpong (2010), the study specified the following private investment function for Ethiopia:

$$
p i=f(c r p s, \text { reer, pui, ir, } r G D P) \text {. }
$$

The model explains that private investment (pi) is subject to changes in credit to private sector(crps),real effective exchange rate(reer), investment(pui),inflation rate(ir) and real Gross Domestic Product(rGDP) among others. Therefore, the econometric version of model was estimated as:

$\ln p i=\alpha 0+\alpha \operatorname{lncrps}+\alpha 2 \ln r e e f+\alpha 3 \ln p u i+\alpha 4 i r+\alpha 5 \ln r G D P+\varepsilon t$

Where $\varepsilon t$ is $1 \mathrm{~N}\{0,1\}, \alpha 0$ represents the constant term of the model and $\alpha 1, \alpha 2, \ldots, \alpha 6$ represents the slope parameters in the model, they represent the respective partial elasticity of each explanatory variable. In stands for natural $\log$ and it is used to transform the data set as it reduces the problem of hetroskedasicity in the estimated model .(Gujarati :2004):

The inflation rate data is not transformed to natural log as it already defined in percentage.

\subsection{Econometric Estimation Procedures}

\subsubsection{Unit Root Testing}

Econometric theory provides various mechanisms to deal with the problem of unit root (non-stationary problem).In this study, the augmented version of Dickey-Fuller (DF) which known as Augmented Dickey-Fuller (ADF) test for unit root was employed as it is advantageous and leads to robust results. The optimum lag-length for the test is selected using Schwarz Information Criterion (SIC). The theoretical ADF was specified as:

$$
\Delta X t=\alpha+\eta t+\lambda X t-1+\sum_{t=1}^{p} \beta \Delta X t-1+\mu t
$$

Where $\alpha$ is constant term, $\eta$ is the coefficient of the time trend, $\mathrm{p}$ is the optimal lag length, $\Delta$ is the difference operator, $\mathrm{t}$ represents the time trend and $\mu$ represents the Gaussian white noise. The test for stationary is carried out under the null hypothesis $\lambda=0$ against the alternative hypothesis $\lambda<0$. Rejecting the null hypothesis for the test statistics larger than the critical value implies absence of unit root(stationary case) and the reverse indicates the presence of unit root.(Gujarati:2004).

\subsubsection{The ARDL Co-integration Testing (Bounds Testing)}

Time series data should have long-run equilibrium relationship and share common trend in order to exhibit cointegration. Thus, to check for the existence of co-integration among the series considered, the study adopted the ARDL model of Pesaran,Pesaran \&Shin (2001) rather than using the convectional co-integration testing approaches. This is because the ARDL approach has some econometric merits over other co-integration testing methods Thus; the following generalized conditional ARDL model was specified:

$\Delta \ln$ pit $=\beta 0+\beta \ln$ pit $-1+\beta 2 \ln c r p s+\beta 3 \ln r e e r+\beta 4 \ln p u i+\beta 5 i f+\beta 6 \ln r G G D P$

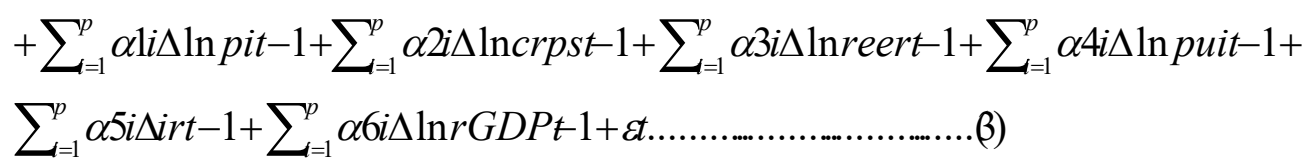

Where the variables are as defined before is the first difference operator; the parameter $\beta i$ except for $\beta 0$ (intercept term or drift) denote the long-run coefficients; $\alpha i$ are the short run parameters of the model to be estimated through the error correction framework in the ARDL model; $p$ is the optimum lag-length selected through Akakie Information Criteria (AIC) and $\varepsilon_{\mathrm{t}}$ is the error term which is assumed to be white noise.

Then, the F-test (Wald test) is used to test the existence of long run relationship among the variables using OLS to estimate the above equation. Consequently, the null hypothesis of no long run relationship $\left(\mathrm{thatis}_{\mathrm{H}} \mathrm{H}_{0}\right.$ : $\beta 1=\beta 2=\beta 3=\beta 4=\beta 5=\beta 6=0$ ) is tested against $\mathrm{H} 1: \beta 1 \neq \beta 2 \neq \beta 3 \neq \beta 4 \neq \beta 5 \neq \beta 6 \neq 0$ (the alternative hypothesis for the presence of long-run relationship).And given the asymptotic distribution of F-statistic is non-standard without considering the independent variables being $I(0)$ or $I(1)$, the appropriate critical values generated by Pesaran et al:2001 based on number of independent variables in the model of presence or absence of constant term or time trend in the model are used in the study. Thus, the calculated F-statistic is compared with two sets of critical 
values developed on the basis that the independent variables are $I(\mathrm{~d})$ (where $0 \leq \mathrm{d} \leq 1$ ).

The lower critical bound assumes that all variables are $I(0)$ whereas the upper critical bound assumes the variables are $I(1)$. If the calculated F-statistics exceeds the upper critical value, then null hypothesis of no co-integration is rejected irrespective of the order of integration. Conversely, if the F-statistic falls below the lower bound then the null hypothesis of no co-integration cannot be rejected; and if the F-statistic lies within the lower critical and upper critical bounds, the test is inconclusive. (Pesaran \& Pesaran: 1997)

Then, in order to obtain the long run coefficients, the following model is extracted from (3):

$$
\begin{aligned}
& \ln \text { pit }=\beta 0+\sum_{i=1}^{p} \beta 1 \ln \text { pit }-i+\sum_{i=1}^{p 1} \beta 2 \ln \text { crpst }-i+\sum_{i=1}^{p 2} \beta 3 \ln r e e r t-i+\sum_{i=1}^{p 3} \beta 4 \ln p u i t-i+ \\
& \sum_{i=1}^{p 4} \beta 5 i r t-i+\sum_{i}^{p} \beta 6 \ln r G D P t i+v t \text {. }
\end{aligned}
$$

Then, the following unrestricted ARDL with error correction representation is estimated so as to estimate the shortrun parameters of the variables:

$$
\begin{aligned}
& \Delta \ln \text { pit }=\alpha 0+\sum_{i=0}^{p} \alpha \operatorname{li\Delta } \ln p i t-1+\sum_{i=0}^{p 1} \alpha 2 i \Delta \ln c r p s t-i+\sum_{i=0}^{p 2} \alpha 3 i \Delta \ln r e e r t-i+ \\
& \sum_{i=0}^{p 3} \alpha 4 i \Delta \ln \text { puit }-i+\sum_{i=0}^{p 4} \alpha 5 i \Delta \ln i r t-i+\sum_{i=0}^{p 5} \alpha 6 i \Delta \ln r D G P t-i+\delta e c t-i+\omega t \ldots .(5) \\
& \quad \text { Therefore: } \\
& \text { ectt }=\Delta \ln \text { pii- }\left[\alpha 0+\sum_{i=0}^{p} \alpha \operatorname{li\Delta } \ln p i t-1+\sum_{=0}^{p 1} \alpha 2 i \Delta \ln c r p s t-i+\sum_{=0}^{p 2} \alpha 3 i \Delta \ln r e e r t-i+\right. \\
& \left.\sum_{i=0}^{p 3} \alpha 4 i \Delta \ln \text { puit }-i+\sum_{i=0}^{p 4} \alpha 5 i \Delta i r t-i+\sum_{i=0}^{p 5} \alpha 6 i \Delta \ln r D G P t i\right] \ldots . .(6)
\end{aligned}
$$

Where $\alpha 1, \alpha 2, \ldots, \alpha 6$ are the coefficients of the short run dynamics; while $\alpha 0$ is constant; $p$ denotes the optimal lag length of the auto regressive process and $\delta$ is the speed of adjustment to the long run equilibrium following a shock to the system; ect $_{\mathrm{t}-1}$ is the error correction term; the residuals from the co-integration equation lagged by one period. $\varpi t \& \mathrm{vt}$ are the respective error terms of the models and all the remaining terms are as defined before.

The error correction term indicates the speed of adjustment to long-run equilibrium in the dynamic model. It is expected to be statistically significant with a negative sign which implies that any disturbance that occurs in the short-run model will be corrected in the long-run. The larger the coefficients of the error correction term in absolute terms, the faster the convergence to equilibrium. (Harris: 1995)

The study has ensured the stability of the model by using the CUSUM and CUSUMSQ tests. The study also tested for the serial correlation, functional form, normality and heterokedasticity associated with the selected ARDL model. The CUSUM and CUSUMSQ statistics are updated recursively and plotted against the breaks points. If the plots of CUSUM and CUSUMSQ statistics stay within the critical bounds of five percent level of significance, the null hypothesis of stable coefficients in the given regression is accepted. (Pesaran et al: 2001).

\section{RESULTS AND DISCUSSIONS}

\subsection{ADF unit Root Testing Result}

As reported in tablel below, the ADF all the variables except inflation rate (ir) are stationary at their first differences for the specification with both trend and drift. Inflation rate is level stationary, I $(0)$. This implies the series are of mixed order of $\mathrm{I}(1)$ and $\mathrm{I}(0)$ and therefore the ARDL methodology is quite appropriate to be adopted for the given time series.

\begin{tabular}{|l|l|l|l|l|l|l|}
\hline \multicolumn{2}{|l|}{ Table 1 ADF Unit Root Test Results } \\
\hline \multicolumn{3}{|l|}{ Level } & first difference \\
\hline Variable & ADF Statistics & Lag & Variable & ADF Statistics & Lag & Decision \\
\hline lnpi & $-2.122967(0.5166)$ & 0 & $\Delta \operatorname{lnpi}$ & $-5.928292(0.0001)$ & 0 & $\mathrm{I}(1)$ \\
\hline lncrps & $-4.232686(0.0103)$ & 2 & $\Delta \operatorname{lncrps}$ & $-5.038066(0.0013)$ & 0 & $\mathrm{I}(1)$ \\
\hline lnreer & $-1.800321(0.6843)$ & 0 & $\Delta \ln (1) e r$ & $-5.790379(0.0002)$ & 0 & $\mathrm{I}(1)$ \\
\hline lnpui & $-2.339111(0.4035)$ & 1 & $\Delta \ln p u i$ & $-11.76221(0.0000)$ & 0 & $\mathrm{I}(1)$ \\
\hline lnrGDP & $0.768909(0.9996)$ & 0 & $\Delta \ln$ rGDP & $-6.558667(0.0000)$ & 0 & $\mathrm{I}(1)$ \\
\hline Ir & $-5.793668(0.0002)$ & 0 & - & - & - & $\mathrm{I}(0)$ \\
\hline
\end{tabular}

The values in the bracket are $p$-values represents first difference and the values in front of the $p$ values are the calculated F- statistics

Source: Author's Computation: 2017 


\subsection{Result of Bounds Test for Co-integration}

Bounds co-integration testing result reported on Table2 shows that the null hypothesis of no long run relationship (no co -integration) among the series is rejected. This is because the calculated F-statistic value equal to 8.641691 exceeds both the upper and lower bound critical values at $1 \%, 5 \%$ and $10 \%$ significance levels. Hence, cointegration (a long run relationship) is witnessed between private investment and the given set of determinants considered.

\begin{tabular}{|l|l|l|}
\hline \multicolumn{4}{|l|}{ Table 2 Bounds Co-integration Testing Result } \\
\hline Significance level & Lower bounds I $(0)$ & Upper bounds I $(1)$ \\
\hline $1 \%$ & 3.41 & 4.68 \\
\hline $5 \%$ & 2.62 & 3.79 \\
\hline $10 \%$ & 2.26 & 3.35 \\
\hline Calculated F-statistics & 8.641691 \\
\hline
\end{tabular}

Source: Author's own Computation: 2017

\subsection{Diagnostics Testing Results}

The results reported on Table 3 shows that model generally passes all diagnostic tests. Thus, there is no evidence of serial correlation as the Brush Godfray LM test failed to reject the null hypothesis; the residual of model is normally distribute since Jaque-Berra normality test is larger than the standard significance level; the model exhibits constant variance as hetrokedatisticity test failed reject the null hypothesis and Ramsey's RESET test for proved that the model has got its correct functional form.

\begin{tabular}{|l|l|}
\hline Table 3 Diagnostic Testing Results for selected ARDL $(2,3,2,3,2,1)$ \\
\hline Test & F-Statistics(Probability) \\
\hline Serial correlation & $2.739744(0.1241)$ \\
\hline Heteroscedacity & $0.948354(0.5670)$ \\
\hline Normality & Jarque-Berra $=1.471601(0.479122)$ \\
\hline Functional form & $0.18228(0.8590)$ \\
\hline
\end{tabular}

Source: Author's own computaion :2017

\subsection{Model Stability Testing Results}

Both the CUSUM and CUSUMQ statistics plotted against the critical bound of 5 percent significance level remain within the critical bound of the 5 percent significance level, and thus, the null hypothesis of stability for all coefficients cannot be rejected.

Figure -1 Plot of Cumulative Sum of Recursive Residuals

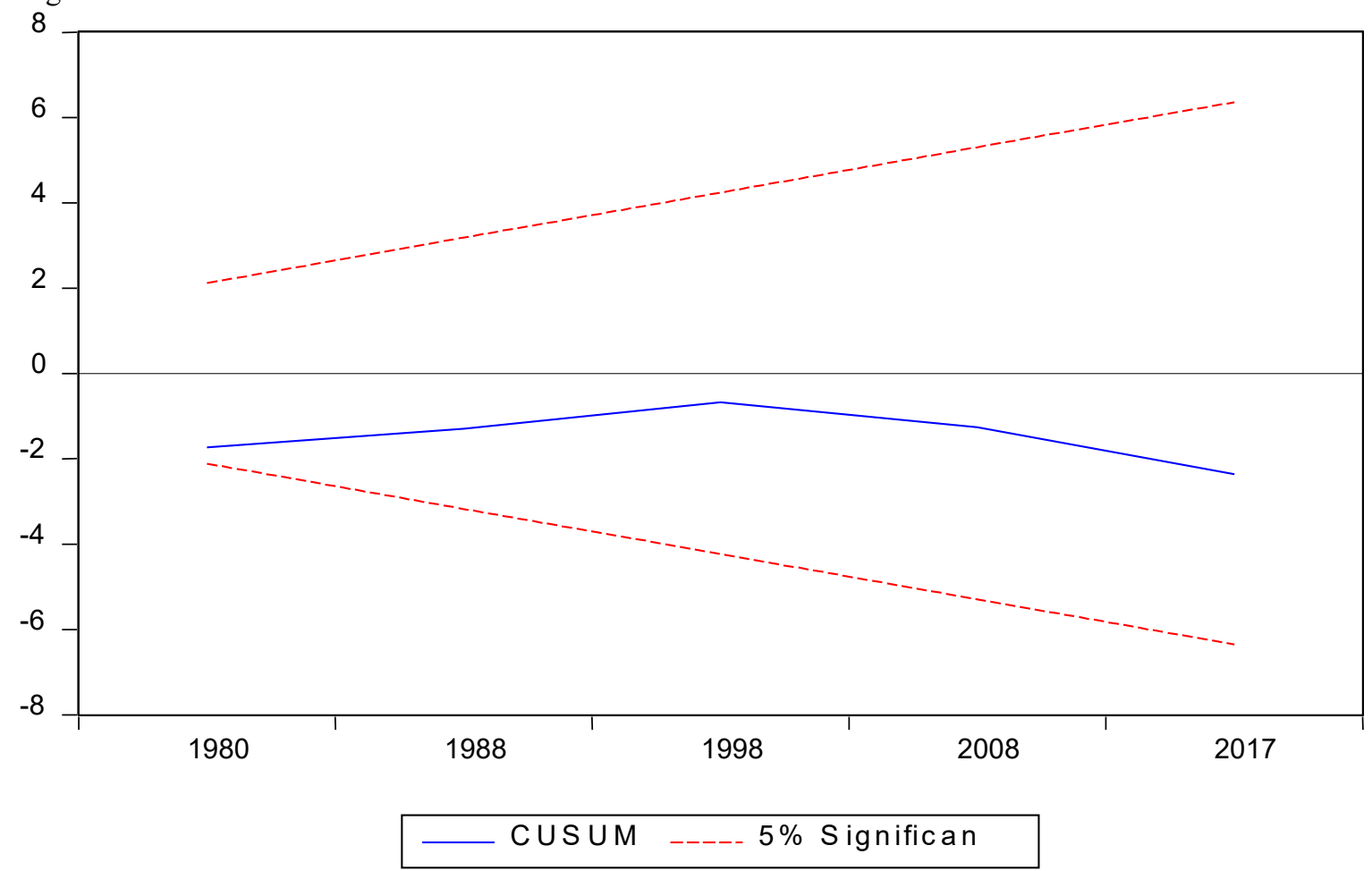

Source: Author's Computation: 2017 
Figure -2 Plot of Cumulative Sum of Squares of Recursive Residuals

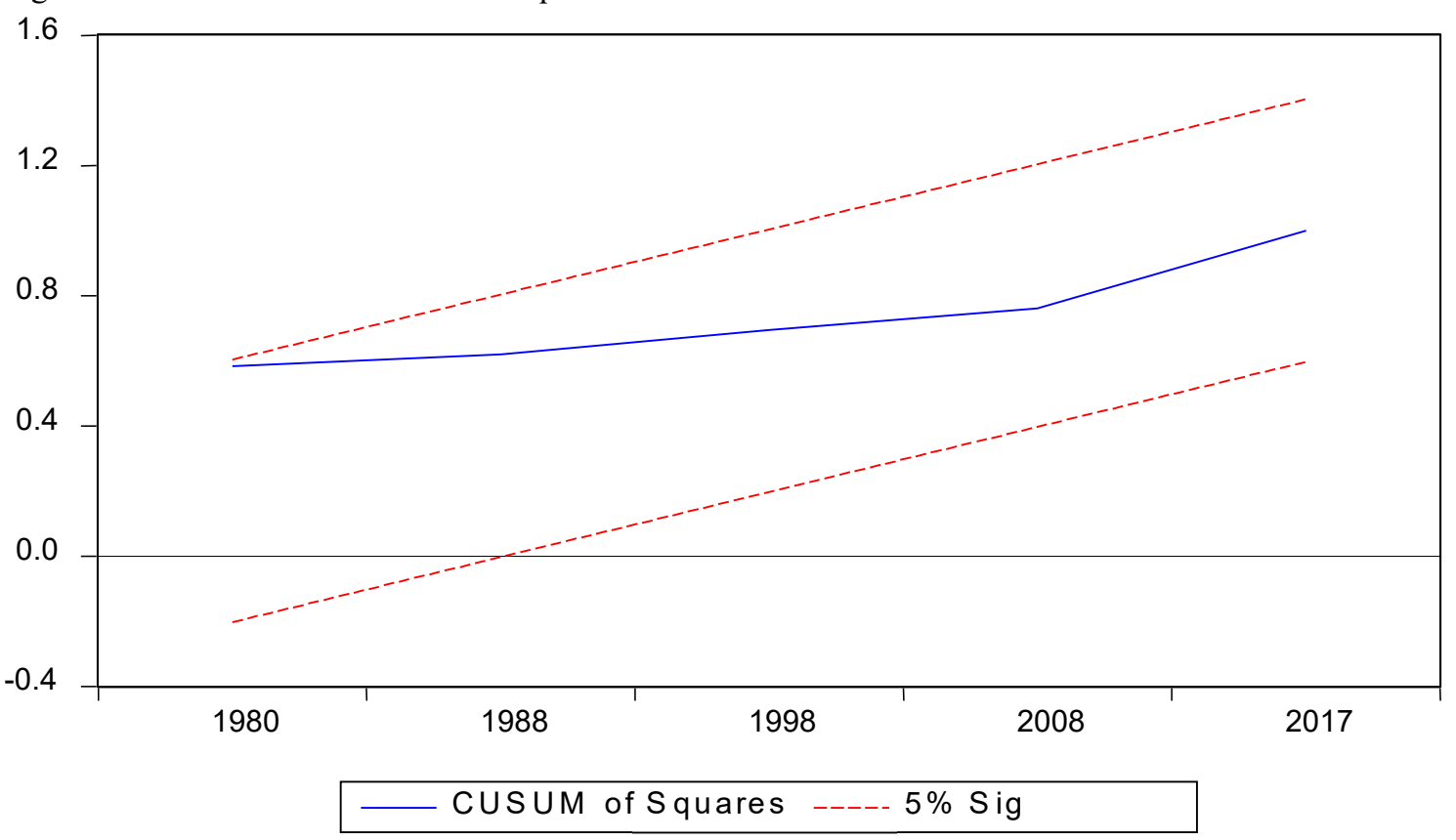

Source: Author's Computation: 2017

\subsection{Long-Run Results}

The empirical model revealed that in the long run, public investment is negatively related to private investment at $5 \%$ significance level. The coefficient indicates that a 1 percent increase in public investment leads to a 0.49 percent decrease in private investment, on average and other things remaining constant. This indicates that, in the long run, an increase in public investment will reduce private investment due to the crowding-out effect, as public and private sectors compete for the same resources in the economy. This supports the finding of Ambachew:2010.However, the finding contradicts with Hailu:2013 which suggests that public investment in the country is primarily concentrated on the development of basic economic infrastructures and social overhead capitals which could lead to crowding-in effect on private investment.

Real gross domestic product has a positive and highly significant effect on private investment. An increase in RGDP by $1 \%$ results to $2.25 \%$ increase in private investment. This is due to the fact that an increase in real GDP of a country will contribute to infrastructural development which in turn contributes to private investment. It can stimulate domestic investment by creating effective demand as disposal income will increase with increased RGDP. Moreover, this finding is in agreement with Wisdom: 2007 \& Abdishu: 2000 who found similar effect of real GDP on private investment. The remaining variables are namely inflation rate and credit to private sector found to be statistically insignificant in long run.

\begin{tabular}{|l|l|l|l|l|}
\hline \multicolumn{2}{|l|}{ Table 4 Estimated Long-Run Coefficients using the ARDL Approach } \\
\hline Variable & Coefficient & Std. Error & t-Statistic & Prob. \\
\hline Lnpi & $-0.495778^{* *}$ & 0.167522 & -2.959485 & 0.0103 \\
\hline Lncrps & -0.300117 & 0.265253 & -1.131435 & 0.2769 \\
\hline Lnreer & -0.889277 & 0.669512 & -1.328247 & 0.2053 \\
\hline lnrGDP & $2.254155^{*}$ & 0.715910 & 3.148657 & 0.0071 \\
\hline In & -0.019510 & 0.015482 & -1.260144 & 0.2282 \\
\hline $\mathrm{t}($ time) & 0.005722 & 0.005804 & 0.985975 & 0.3409 \\
\hline constant & -12.643899 & 13.861018 & -0.912191 & 0.3771 \\
\hline$* * * *$ denote significance at 1\% \& 5\% respectively; t denotes trend and cons stands for constant. \\
\hline
\end{tabular}

Source: Author's computation: 2017

\subsection{Short-Run Results}

The coefficient of the estimated error correction model (ECM) is estimated at -0.7825 and it is statistically significant at 1 percent. The negative sign of the coefficient of the error correction model indicates that short run shock was above the long run equilibrium value and therefore the adjustment towards the long run equilibrium will be taken place by decreasing (declining). Thus, the short run equilibrium value will adjust by $78.25 \%$ within 
a year .Moreover; the value of the R-Squared implies that about $89.5288 \%$ of variations in private investment are explained by the variations in the independent variables considered. Therefore, the goodness of fit of the short run model is proved to be strong. The F-statistics of joint significance shows that all the independent variables considered are statistically significant in jointly explaining the model.

The short run estimate of the ARDL model shows that the relationship between public investment and private investment is negative and statistically significant similar to the long-run case. The negative relationship between public investment and private investment showed that public investment crowed outs private investment, thereby reducing the economy's potential to generate and sustain more output. Crowding out effects are highly pronounced where public investment majorly financed from increased taxes, which reduces level of savings, and by increasing borrowing from domestic markets, which pushed up domestic lending rates, and also leads to credit rationing in the private sector.

The impact of real gross domestic product on private investment in the short run is also similar to that of the long run impact, it is positive. This indicates that in the short run also as the real GDP of the country increases the income of citizens can increase and they can save more, and this in turn will increase private investment.

The relationship between credit to private sectors and private investment in the short run is in contrast to the long run relationship. Credit to private sector is found to have a positive impact on private investment in the shortrun and it's significant at $10 \%$ level. Credit to private sector is channeled through financial institutions which mobilize savings and advance credit borrows. Therefore, availability of credit to the private sector in the short-run affects private investment positively. The result supports the finding of Osmond: 2015. Inflation rate and real effective exchange rate are also insignificant to effect private investment which may indicate ineffectiveness of the respective policies.

\begin{tabular}{|c|c|c|c|c|}
\hline Variable & Coefficient & Stand. Error & t-Statistic & Probability \\
\hline $\mathrm{D}(\operatorname{lnpi})$ & $-0.318652 * *$ & 0.144662 & -2.202730 & 0.0449 \\
\hline $\mathrm{D}($ lncrps $)$ & $0.561264 * * *$ & 0.307680 & 1.824183 & 0.0895 \\
\hline $\mathrm{D}$ (lnreer) & 0.241517 & 0.461612 & 0.523203 & 0.6090 \\
\hline $\mathrm{D}$ (lnpui) & $-0.136055^{*}$ & 0.037780 & -3.601232 & 0.0029 \\
\hline $\mathrm{D}(\ln \mathrm{GDP})$ & $2.394974^{*}$ & 0.577325 & 4.148399 & 0.0010 \\
\hline $\mathrm{D}(\mathrm{ir})$ & 0.005795 & 0.005577 & 1.039085 & 0.3164 \\
\hline $\mathrm{T}$ & 0.003537 & 0.003413 & 1.036548 & 0.3175 \\
\hline cointEq(-1) & -0.7825 & 0.149957 & $-4.122412 *$ & 0.0010 \\
\hline \multicolumn{5}{|c|}{ R-squared $\quad 0.895288$} \\
\hline Adjusted R-squared & 0.745699 & F-statist & $98498(0.000$ & \\
\hline
\end{tabular}

Source: Author's own computation: 2017

\section{CONCLUSION}

The study ascertained the major determinants of private investment in Ethiopia using data over the period 19802017.The Autoregressive Distributed Lag (ARDL) bounds test approach to con-integration was employed along with ADF unit-root tests and the convectional tests for reliability of the models. The empirical results showed that private investment and its determinants considered(i.e. public investment, real gross domestic product, real effective exchange rate, credit to private sector and inflation rate)are co-integrated. Besides, the error correction coefficient estimated at negative 0.7825 is highly significant which further confirmed the existence of a stable long-run relationship among the data series. The major findings of the empirical models revealed that public investment had a negative and significant impact on private investment while real gross domestic product had a positive and significant effect on private investment both in the short-run and long run. Credit to private sector is also found to have positive impact on private investment of Ethiopia in the short run. After all, the implication of the study is that private investment in Ethiopia is mainly determined by real GDP and public investment. Thus, the economy needs to sustain the economic growth (i.e. growth in real GDP) and overcome the crowd-out effect of public investment on private investment.

\section{REFERENCES}

Abdishu Hussien(2000),Factors that Determine Private investment in Ethiopia, https://archives.kdischool.ac.kr, [Accessed 10.6.2017]

Ambachew Mekonnen(2010), The Determinants of Private Investment in Ethiopia, A Time Series Study,Ethiopian Journal of Economics, Volume XIX, No. 1,pp.75-126 .

Deneke,Solomon (2001), "Private Sector Development in Ethiopia, International Conference on African 
Development Archives. Paper 19,http://scholarworks.wmich.edu/africancenter icad archive/, [Accessed 9.3.2019]

Damodar N. Gujarati(2004), Basic Econometrics,(in: McGraw-Hill Publishing -Ed):New Delhi, India

Francis Naa-Idar,Desmond Tutu Ayentimi and Joseph Magnus Frimpong(2012),A Time Series Analysis of Determinants of Private Investment in Ghana (1960-2010), Journal of Economics and Sustainable Development , Vol.3, No.13, pp.23-33

George Marbuahand Magnus Frimpong(2010), The Determinants of Private Sector Investment in Ghana: An ARDL Approach, European Journal of Social Sciences, Vol.15, No. 2 ,pp.250-261

Hailu and Debele (2015), The Effect of Monetary Policy on the Private Sector Investment in Ethiopia,ARDL CoIntegration Approach Economics Vol. 4, No. 2, 2015, pp. 22-33

Harris, Rv.(1995), Using Co integration Analysis in Econometric Modeling, London: Prentice Hall,https://www.scirp.org , [ Accessed 10..2017]

Juthathip Jongwanich and Archanun Kohpaiboon(2008),Private Investment: Trends and Determinants in Thailand, World Development, Vol. 36, No. 10, pp. 1709-1724.

Khan, Mohsin \& Reinhart, Carmen (1990),"Private investment and economic growth in developing countries," World Development, Elsevier, vol. 18 ,No.1, pp.19-27.

M.Hashem Pesaran, Yongcheol Shin and R.J. Smith (2001),Bounds Testing Approaches to the Analysis of Long Run Relationships, Journal of Applied Econometrics, Vol. 16 No.3, pp. 89-326.

Mario Blejer and Mohsin Khan(1984),Government Policy and Private Investment in Developing Countries, https://econpapers.repec.org, [Accessed 8.3.2019]

Mima Nedelcovych and David Shiferaw(2012),Private Sector Perspectives for Strengthening Agribusiness Value Chains in Africa, www.value-chains.org > dyn > valuechains > docs > detail2, [Accessed 8.3.2017]

Siraj Mustefa(2014),Private Investment and Economic growth Evidence from Ethiopia, https://opendocs.ids.ac.uk, [Accessed 8.6.2017]

World Bank(2013), Smarter Regulations For Small And Medium-Size Enterprises,http://documents.worldbank.org/curated/en/,[ Accessed 15.6.2017]. 